Caribbean Routes: Ethnographic Experiences, Theoretical Challenges, and the Production of Knowledge

\title{
How to listen to an Afro-Caribbean landscape
}

\author{
Claudia Fioretti Bongianino'
}

'Universidade Federal do Rio de Janeiro, Laboratório em Antropologia e História, Museu Nacional (LAH/MN/UFRJ), Rio de Janeiro/RJ, Brasil

\begin{abstract}
Using my 14-month ethnographic research at Old Bank, in the Caribbean coast of Panama, I seek to map how the domains I knew of this village were shaped by the multisensory relationships I established with my interlocutors and the spaces in which they lived, circled, and projected their voices. In dialogue with the Caribbean literature, I show how the locally established contrasts between before and today, as well as the existence of the distinct neighborhoods of the village, expressed the historical process of space occupation, based on the use, inheritance and collective ownership of family land. Finally, connext Ingold's argument about landscape with ethnographic data, underlining how Old Bank's time and space are created through the relationship between human beings and God.
\end{abstract}

Keywords: Landscape; Family Land; Afro-Caribbean; Panama. 


\section{Como escutar uma paisagem afro-caribenha}

\section{Resumo}

Com base em pesquisa etnográfica de 14 meses em Old Bank, na costa caribenha do Panamá, busco mapear como os domínios que conheci desta vila foram moldados pelas relações multissensoriais que estabeleci com meus interlocutores e com os espaços em que eles viviam, circulavam e projetavam seus gritos (sháut). Em diálogo com a literatura caribenha, mostro como os contrastes localmente estabelecidos entre "antigamente e hoje, assim como a existência dos distintos bairros da vila eram expressões do processo histórico de ocupação do espaço, fundado no uso, herança e posse coletiva da "terra familiar". Por fim, traço uma ponte a argumentação de Ingold sobre paisagem e a análise etnográfica, sublinhando como a formação dos tempos e espaços de Old Bank se da a partir das relações dos seres humanos entre si e também com Deus.

Palavras-chave: Paisagem; Terra familiar; Afro-Caribenhos; Panamá. 


\title{
How to listen to an Afro-Caribbean landscape
}

\author{
Claudia Fioretti Bongianino
}

Gaia was in Panama City visiting her daughter and going to the doctor's when her son, Arny, was telling me about the small, one-bedroom apartment built right below her house, which was let out to "people like you" (pipl láik iú, in the local idiom¹) - meaning, in this case, people like me.

It is very central, with this front porch, where you can sit and talk to people who pass by Main Street. If you decide to rent the apartment, you can move in as soon as next week, when my mother comes back from her trip. God first!

I decided to accept his offer that same day, and even if there was no way of knowing it at the time, I would end up living there for most of the 14 months I spent doing fieldwork in Old Bank. Nor could I know then how much and exactly what I would learn in the process. Taking my interaction with Gaia as a starting point, in this article I map the ways people in the village speak of spatial and temporal dimensions, building relations in which God is always evoked as a participant. In the first section, I focus on the expression "people like you" and describe, on the one hand, how Gaia, her close kinspeople and I were seen in Old Bank, and on the other, what we saw and heard from her house. Moreover, I will make evident how the domains I got to know in Old Bank were molded by multisensorial relations that I established with my interlocutors, in the spaces within which they dwelled, circulated and from which they projected their "shouts" (sháut). In the second section of the article, I recall the first conversations I had with Gaia, underscoring the unexpected answers I received to questions about the history of the village and its families.

These answers Gaia provided are explored in the final sections of the article. In dialogue with the reflections of Edith Clarke (1999 [1057]) and Jean Besson (2002) on land and family in the Caribbean, I show how the existence of distinct neighborhoods in the village expresses the historical process of occupying the land, which is based on usage, inheritance, and collective ownership of "family land" (fámili lánd). I then analyse the locally established contrasts between "first time and today" (fârst táim an tudie), which are manifest in the spatial configurations of the village, in particular in the diametrical opposition between the location of the Methodist Church and the graveyard in the village. Finally, the last section links Tim Ingold's (1993) arguments on "landscape" with the way that relationships among human beings themselves, and also between human beings and God, together form the times and spaces of Old Bank.

\section{The village, the house, and the shouts}

When Arny told me about the room below Gaia's house that she rented for people like me, he added that it was one of the local buildings leased to people who intended to reside "in Old Bank" (pan Uôl Bánk) for months. That is how I learned the name of the Panamanian village I was living in: Old Bank, in English, the literal translation my interlocutors used for Uol Bánk, the village's name in the local language. When I say I only leaned the name at that moment, it is because in Spanish, the official language of the country, the village is called Bastimentos, and it is described as a place of some $1.3 \mathrm{Km}^{2}, 738$ inhabitants and 193 houses (INEC 2009-2010). Situated on the Atlantic coast of Panama, around $30 \mathrm{Km}$ from the border with Costa Rica, and entrenched in the northwest corner of Bastimentos Island, the village of Old Bank faces west to the powerful waves of the Atlantic Ocean, and south to the calm waters of Almirante Bay.

\footnotetext{
1 The local idiom is called Guari-Guari, and does not have a standardized oral or written form. I have thus adopted an informal phonetic approach in transcriptions. For linguistic details, see: Snow 2007; H. Reid 2013; Spragg 1973; Justavino 1975; Brereton 1992; Aceto 1995.
} 
These same waters bathe the archipelago of Bocas del Toro and the homonymous region that extends, from the archipelago, a few kilometers into the continental Panama.

Old Bank could only be reached by boat, after a plane trip that ended at the regional capital (traveling from Panama's or Costa Rica's capital), which my interlocutors called Bocas Town (again, their literal English translation for the local name, Buocas Taun, that was officially called Pueblo de Isla Colón, in Spanish) and was located in the neighboring island of Colón. Another way to arrive at the regional capital was by taking a bus trip from Panama's or Costa Rica's capital to the neighboring port of Almirante, in continental Panama. In November 2013, it was the bus option from Panama's capital to Almirante, followed by two boat trips, first to Bocas Town and finally to Old Bank, which got me there. During this last boat trip, my gaze was drawn to the exuberant landscape, which presented all of the characteristics one would expect from the famous tourist destination known as the "Panamanian Caribbean" (Guerrón-Montero 2006: 633): emerald waters; white sandy beaches with crystal-clear water; dazzling forests of palm trees, banana trees and other tropical species. In the midst of all this, there emerged, here and there, houses built on stilts carved into the ocean or on land, clustered along the slope.

In style of most local houses, Gaia's had been built on stilts dug into the land. This formed a wooden structure which served as a foundation for the house, made of wooden walls and a zinc roof - materials which allowed sounds to easily propagate through rooms and homes. Located on the second floor, the house was accessible by a side stairway, which led to a veranda that took up the whole façade, leading to the entrance. The interior was, in principle, empty, though it could later be closed in with cement walls, such as those that made up the apartment I was living in.

According to Arny, the specific piece of "land" (land/ tierra) I was living in measured some $48 \mathrm{om}^{2}(20$ $\mathrm{x} 24$ ), but it included his mother's house ( $128 \mathrm{~m}, 8 \mathrm{~m}$ by $16 \mathrm{~m}$ ), the surrounding yard ( $52 \mathrm{~m}$ ) and the two simple hotels, built on stilts dug into the water so as to take in the best views of the bay (each hotel with $150 \mathrm{~m}, 6 \mathrm{~m}$ by $25 \mathrm{~m}$ ). In the village, this was the average size of plots occupied by more than one house belonging to different members of the same family. Most houses were similar to Gaia's in size and frequently had apartments constructed below them. The main difference, though, was that most houses and apartments built in a family's plot were usually occupied by kinspeople, not by tourist developments - such as hotels and apartments rented out to people like me. Unlike Gaia's yard, others also typically lacked the two water tanks that stored the village's water. These were not only expensive in themselves, they also had high maintenance costs, much of it because of piping (around US $\$ 1000$ per tank, plus piping installation, while the village's water costed was around $U \$ 10$ per month).

Most yards contained fruit trees or small gardens, intended for domestic consumption, and some families also had "forest gardens" (fárm pán di bush or finca en el monte)3, occupying areas that spanned between one and five hectares in the forests surrounding the village or in nearby islands. As I will describe shortly, Gaia had such a "forest garden" in the past, but no longer owned them. In time I came to realize that the differences between Gaia's house and those of most villagers were both symptom and cause of the relations they established among themselves. Gaia and her kinspeople were among the wealthiest villagers, owned most of the tourist developments in the village, and lived in some of the largest houses, decorated with more furniture than average homes. Like other villagers who also differentiate themselves socioeconomically, they had a critical

\footnotetext{
2 My interlocutors use the native term "land" (land/ tierra), rather than "piece of land" or "plot". This seems to me to be related to the fact that, for them, land is not immediately quantifiable, established by limits or borders, juridically titled, or something that can be bought or sold. However, in order to make the text more coherent, I have translated their native term as "piece of land" or "plot". The differences between these conceptions of land will be explored throughout the article.

3 The native concept of "fárm pán di bush or finca en el monte" refers to a piece of land in the forest where a person usually does not build a house, but grows vegetables and fruits in the midst of the forest vegetation. Such pieces of land do not have explicit borders, neither are they completely cleared of existing vegetation before the person plants his or her garden. Therefore, I chose to translate it as "forest garden".
} 
stance regarding local habits, and Gaia's grandchildren tended not to play with other children and teenagers, especially because they studied in Bocas Town. Many of the villagers saw this as an intentional effort made by the family to distinguish themselves from others, in relation to whom they purportedly felt superior. Many thus preferred to keep their distance from Gaia and her relatives.

At the same time, however, many of these differences made it easier for me to get close to her. Gaia, after all, owned an apartment for people like me: foreign, White, with greater spending power than most of the local population, interested in residing in the village yet used to certain comforts that were not available to all villagers, such as a water tank, piping systems, and running water all day long. Gaia's apartment was also perfect for people like me, an expression that included another important aspect. In Old Bank I was seen as a single woman, since I lived alone, even though I wore a ring and claimed to be married. I was also seen as a young woman, not necessarily because of my age, but because I did not have children, which is usually the watershed between youth and womanhood. For this reason, I wanted to live in a room close to (or inside) the house of a woman, with whom I could interact more freely, without having to worry about possible harassment, abuse or gossip.

Since Gaia and I lived in the same building, even if in different homes, we would inevitably keep track of each other's activities, sometimes by sight, but mostly by listening - a sense that, in Old Bank, seems to be more preeminent than the others. I would daily hear her voice and footsteps, as well as those of people who visited her home - much as she, no doubt, heard what went on in my apartment. We also heard shouts of the neighbors, calling each other from within their homes or from the outside. Analogously, we would hear those who passed by on the street and shouted: "Gaia!", to call her. Or those who merely shouted "Good Morning Gaia!", upon seeing her door open, and passed on by.

With time, similar shouts began to characterize my interaction with my host and with other people who attended her household. Before meeting them, I became acquainted with their voices as they shouted after Gaia, and spoke with her. Crossing the tenuous boundaries that separated my apartment, the house of my host, the yard or the street, their voices found their way to me.

Auditive contact does not end there: gradually, these and other people started to direct their voices to me. They would greet me when they passed by my apartment and saw the door ajar, or when they met me at the front porch, stopping for quick conversations. Timidly, I began to do the same when I passed close to their houses, and those of other people who I gradually came to know in Old Bank.

I thus noticed that one of the essential aspects of the houses in Old Bank was the importance of the external space, that is the verandas, porches, yards and adjacent streets. All of these open spaces appeared to be inserted into the local concept of the "home" (huom), a fact that became particularly evident when adults, before going out and leaving the children alone, would ask a child to "not leave the home", which, however, meant that they could stay in areas adjacent to the residence, including the yards of neighboring houses and the streets. These open spaces were furthermore locales in which most of the socialization took place, particularly with those who lived in other houses, but also, often, with those how lived in the same home.

In this context, the act of calling after someone at a distance with a shout (sháut) was noteworthy not only for being frequent, but also as one of the central elements of socialization in the village. Indeed, a visit began by shouting out the name of person from outside her home, and receiving a reply shouted back, rather than by banging on someone's (open or closed) door or approaching it directly and looking inside the house with no warning. The act of shouting corresponded, above all, to a quotidian way of relating to people, greeting them when passing by their homes, and to maintain brief, but important, social interactions.

Shouts imposed themselves on the soundscape of the village, which was not, by any stretch, otherwise silent. Except for some very hot afternoons and during the dawn, the place was infused by the shouts of people and the music that blasted from the village's speakers. The presence of surrounding people was thus constantly 
perceived by hearing them, even before it was possible, for example, to smell the food they were preparing or to see them. In particular, this preponderance of hearing forced me to reflect on the fact that it seemed to be the sound (of voices and music), and not the proximity of bodies, that physically brought people together in an auditive copresence. Indeed, while hearing emerged as the central sense, touch seemed to be marginal, with actual contact between bodies being quite rare. Fortunately, I was quickly taken in by the shouts, which gradually brought me closer to people with whom I interacted periodically, when they passed by my house, or when I passed by theirs's, or simply when we ran into each other in the village and called out each other's names before we greeted. And it is interesting that the first person I became close to through these shoutmediated encounters was precisely Gaia - and not her son, for example, who I met first, but whose shouts I did not encounter as often as hers.

\section{Speaking about families, histories, places}

On the day I moved into Gaia's apartment, she came down the stairway that lead to her home and, upon seeing my door open, shouted out my name. When I went out into the porch, I saw her, roughly seventy years of age, carrying in her hands a dish covered in aluminum foil. "I cooked ráis an bin and brought it for you to try the food from here. I hope you like it. It's rice cooked with beans and coconut milk!" I asked her if she had already had lunch or if we could eat together, and she invited me to eat in her home. A few days later, seeing Gaia on her veranda, I shouted out her name and she invited me to go up and sit with her. On both occasions, I tried to carry out one of the semi-structured interviews that I had prepared before leaving for the field: "Gaia, can you help me with the research I am doing here about the history of Old Bank and its families? I'd like to start by hearing a bit about the history of your family".

My family? I don't know much, but my paternal great-grandmother told me that her husband was Black and came from Jamaica. I did not know him and can't remember his name. But his surname was Jones, like my father's and my own. He died before I was born and I only knew my great-grandmother, his wife, who told me about him. She was White and had straight hair. I don't remember her surname. She was White Indigenous (Uait Indígena), from Blue Fields in Nicaragua.

When Gaia's great-grandfather arrived in Old Bank, the area that today makes up Nicaragua was part of Colombia, as was Panama and the islands of San Andrés and Providencia - the latter two are still parts of Colombia. My hostess referred to this period in time as being "first time", but she did not know much about it - that is, about the land of origin of her grandparents, their ethno-racial identity, their life outside of Old Bank, or the reasons that brought them there - except for an economic dimension: the presence of the Banana Industry. Her grandfather had been hired to work with bananas, having probably moved between the different plantations associated with the industry along the Atlantic Coast of Central America, between the present-day territories of Nicaragua, Costa Rica and Panama - just like many Afro-Caribbean people had done between the 1800 s and 1900 ( $c f$. Putnam 2002, 2013).

Her paternal and maternal great-grandparents were the oldest ancestors that she knew anything about. She learned of them either because she actually met them, or because she heard stories told by people she knew, especially her grandmothers or parents. These stories centered on the Banana Industry, but contained a further economic marker that attracted "Black Caribbean" people to Old Bank - the construction of the Panama Canal. Since she descended from these Caribbean migrants, Gaia identified as Afro-Caribbean and extended this classification to all of the villagers. Although she also recognized that her grandmother was "White Indigenous" from Nicaragua, it was the Black ancestry of her other grandparents, from Jamaica and San Andrés, that she underscored when accessing the native ethno-racial concepts of "Black Caribbean" or 
"White Indigenous". And these concepts were more closely tied to the ways the villagers experienced skin color in interpersonal relations (leading them to define it as black or white), than to a purely ethnic ancestrality or identity (such as Afro-Caribbean).

In the answer Gaia gave me, she was furthermore careful to note the fact that her ancestors had married people they met while moving through different places, before finally settling in Old Bank.

My father said that his father and grandfather - my grandfather and great-grandfather - had many lands [here in the village and its surroundings]. They bred cattle, planted bananas and sold them to the Banana Industry, which exported and sold them. [...] My great-grandfather had a lot of money and land. These were on neighboring islands as well as here, where he owned all the land in Mégl Bánk. A man whose surname was Taylor owned the lands that stretch from the bridge on ôt Yánda until Dág Wúd, as well as the rest of the lands in Old Bank. In Dôn di Crik I think it was a Davies. When they arrived in Old Bank, there was no one here it seems, not even Indigenous people, so the two occupied the land and, little by little, gave parts of it to those who arrived later, allowing them to build their own houses and to plant on unused land. For example, when [...] the Evans arrived, the Taylors gave them land to live on and to cultivate on the Evans Hill.

"So the first families of the village were the Taylors, the Joneses and the Davies, followed by the Thomases and the Evans?", I asked:

Yes, the members of these five families married with one another and with people from outside, who arrived later on, including the Chineses, Ngobe Indigenous people, and European White people. These families are still the largest in the village, along with the Lorchiney, the Johnsons, the Martins. But we are all one family here. As we say, uí dé al fámili, bót uí no liv al láik famili.

That afternoon, as I spoke to Gaia on the veranda of her house, I took detailed notes, but was lost in the maze of the surnames she referred to, as well as the names of different places in the village and the range of local terms, with which I was not yet familiarized. "Ui dé al famili?”, I repeated, making an effort to ensure that I had correctly jotted it down in my notebook, and also to practice the local language, which I had not yet learnt. "Yes, we are all family, but we don't all live like family" (nosotros somos todos familia, pero no vivimos todos como familia)". My hostess reformulated what she said in Spanish, as if that phrase, once translated, were self-explanatory.

Gaia and the other villagers often acted this way. In general, they spoke as if I were as acquainted as they were with the fact that all of them in Old Bank "were family", or with the differences between "first time" and "today". They seemed to suppose that, like them, I knew people with the surnames they mentioned, and had walked through all of the neighborhoods of the village. How was I to deal with what my interlocutors took for granted, but which, for me, still needed to be grasped?

\section{We are all [one] family}

Trying to situate myself in the midst of the information that was being transmitted to me in bulk, but which remained somewhat unclear, I sought to sketch images - maps and genealogies - that would help me to understand narratives like Gaia's. She at once connected the history of the village and of one of its families, and also these two stories with the arrival of Black ancestors from the Caribbean, of Whites from European countries (or from their American and Caribbean colonies), and of Amerindians from Central America. Furthermore, the stories established associations between the occupation of land and the distribution of this same land through interpersonal relations that existed between the ancestors. Alongside these correlations, the differences between the various neighborhoods of the village, as well as between the surnames, were likewise emphasized. 
Limits were thus drawn between kinspeople and pieces of land, which were, at the same time, attenuated by the claims that, in Old Bank, "we are all family", despite the fact that not everyone "lived like family".

I stated showing to the people I interviewed the maps of the village I managed to find and asked them to draw others, while addressing questions to them about neighborhoods and people they knew who lived in each one. At the same time, I asked them to list their kinspeople in generational order and to tell me about their children, then about their parents and their parents' children and grandchildren (that is, Ego's brothers and nephews). I then moved on to paternal grandparents and their children and grandchildren (uncles and cousins of Ego), later doing the same for maternal grandparents and other known ascendant kin. I asked these questions to Gaia and to nine other women. In 2015, I carried out an analogous, but more succinct, exercise, by helping to create the school census and asking residents about the surnames of their grandparents.

Significantly, the genealogy of the people with whom I spoke was always marked by the same kind of historical event: the time their first matrilateral and/or patrilateral ancestor arrived in Old Bank. These ancestors - or in a more analytical formulation, these founding ancestors - were the most distant ascendant kinspeople who interviewees had knowledge of, most being described as Black people from the Caribbean. Others, however, were described as White Indigenous (Uait Indigena) from Nicaragua, White Europeans from the United Kingdom, Ngobe Indigenous people and Chinese. The eight interviewees had invariably learned of these people through stories narrated by their grandmothers, although on some occasions such stories were also told by their grandfathers or parents. Furthermore, each one had, as one of their ancestors, someone with the same surname as the founding ancestors mentioned by Gaia- that is, five men whose surnames were Jones, Taylor, Davies, Evans or Thomas. All of them thus traced their descent from at least one of these five founding ancestors, and, through this link, they explained their self-identification as Afro-Caribbean, and also justified the claim, common throughout the village, that "we are all [one] family".

The common reference made by my interviewees to either European, Ngobe Indigenous people or Chinese ancestors was explained to me as being a feature of post-1920 migrations, and therefore to events that occurred after the arrival of the Afro-Caribbean founding ancestors - which occurred, during the construction of the Panama Canal in 1914. The presence of the Ngobe and Chinese in Old Bank was linked to the Banana Industry, which had its heyday in 1930 (Bourgois 1985), while other foreigners mostly arrived with the development of the tourist industry in the village and in the Boca del Toro region, which took place during the 199os and 200os (Clairborne 2010; Spalding 2011).

Informal school census data and genealogies provided me with valuable demographic data on the village, but they also brought to light some unexpected information. My interlocutors would often interrupt their list of kinspeople, suddenly changing the subject. Or, rather, they foregrounded another theme - the matter of land - that at first seemed to me unconnected to genealogy and to my questions about the history of the village and its families.

Once, a woman whose surname is Davies told me: "Before marrying me, my husband lived in one of the bays of Bastimentos Island. He had many plots, but they were sold by the people who had asked my family to live in the land that belonged to him". On another occasions, an interviewee whose surname was Edwards made an analogous comment:

My grandfather had many plots which were stolen. I have a document from 1905 which proves that the land belonged to my grandfather, and it should therefore belong to my family. Others went to court with more recent documents declaring that the land was theirs, and that I had lost the right to it. The older documents should have greater value, not the other way around. People make fake documents and buy employees to win over plots in court, and we lose what used to be ours. Many of the plots I used to have were stolen by people who then sold them without having documents and "today" those who bought it have a document. 
Another interlocutor stressed this point: "Today, with tourism, some relatives started to sell parts of our "family land" without permission. It was "family land"; they couldn't sell it without authorization. This is theft!". Faced with this fact, some of the women I interviewed (as well as other villagers, of both sexes) had gone to court to claim land which, in their words, had been "stolen". Nonetheless, most said that they would rather leave things as they are, arguing, rather generically, that they preferred to "avoid fights and problems". Only two offered a more precise justification: "To avoid obeá, witchcraft".

In a manner I had not predicted, the matter of land pervaded my conversations on history and family as something, at once, constitutive and disruptive of local relations, providing a reason as to why people would often follow the claim that "we are all family" with the caveat "but not all of us live like family". By speaking of the temporality of "first time", local residents effectively emphasized that founding ancestors had distributed part of their land to those who arrived afterwards. Relations between families were hence mediated by gifts of land, creating and straightening the ties between them. However, the ownership of land was not established by rigid criteria, thus increasing conflicts, accusations of theft, fights, and problems that eroded the relations between kinspeople, and which could result in much-maligned witchcraft accusations.

The women I spoke to explained that the pieces of land in the village did not correspond to individual properties, but to collective ones. In other words, they were described as "family land". This sort of collective ownership of land shows remarkable similarities to the Caribbean logic of Family Land ${ }^{4}$, described in Edith Clarke's (1999 [1957]) pioneering study of Jamaican kinship, and investigated further in other analyses of collective land ownership in the Black Caribbean (cf. Mintz 1974; Besson 1984; Trouillot 1992; Olwig 1999; Carnegie 1987; Crichlow 1994). According to Clarke, in its primary meaning, the Family Land was a piece of land received by the ancestor or ancestress, following emancipation from slavery, having been gifted to them by their former "lord". In Old Bank, though, "family land" was freely occupied by the first founding ancestors, whose surnames were Jones, Taylor and Davies. Later, it was distributed to the founding ancestors of the families that arrived later, with surnames such as Evans, Thomas, etc.

Yet, much like Caribbean institution of Family Land, the logic of use, inheritance and ownership of land in Old Bank, known "family land", stipulated that land could also be entrusted to a kinsperson (officially an owner of the land). At any rate, it belonged to the family and could not be alienated. "Family land" was transmitted as inheritance to descendants of both sex that were linked (by blood or surname), through the maternal or paternal side, to the ancestor who originally occupied or received the plot. More specifically, everyone who had the same surname or the same blood as the ancestor were inheritors, and, as Gaia taught me, blood was transmitted to children by the mother and the father, while the surname could be transmitted by one or the other or both. Ultimately, no one was entitled to sell "family land", since, to do so, they would need the unanimous consent of all descending and ascending relatives (by blood or surname), which is practically impossible since even those relatives who were yet to be born and those who died would have to acquiesce.

As Clarke (1999 [1957]) notes in her consideration of inheritance of Family Land, the collectivity which is referred to by the term "family" included all those who were alive, even those who lived far away and had not settled on the land for a long time, since they might always return to it, cultivate it and, eventually, build a house on it. The only two conditions were that there was still room to do so and that the person who wanted to do so was in real need. This "family" collectivity also included all of the past and future generations, even adopted children or those born out of wedlock. However, this "family" collectivity did not include husbands and wives of the descendants of the ancestors, nor children they may have had with other partners. In other words, it included all descendant relatives (by maternal or paternal blood or surname), but no affinal relatives.

4 Family Land, in capitals, refers to the widespread Caribbean concept, as discussed by authors such as Clarke (1999 [1957]) and others, while "family land", in quotations, refers a native concept used by the villages of Old Bank. 
Jean Besson (2002: 281-291) took Clarke's analysis further and described the Caribbean family as a group that is defined, precisely, by the ownership of Family Land. The author thus departed from analyses that defined these groups by exclusive criteria, such as consanguinity, alliance or filiation, according to which they would compose a closed unit. Instead, Besson proposed a conception of the family focused on the control of the gradual swelling of the group through conjugal relations, since, in the logic of Family Land, only sons and daughters - not partners - were incorporated into the inheritance group. In this way, she introduced a concept that was open to time and space, since, by the logic of Family Land, sons and daughters continued to be heirs, even if they lived far away, did not occupy the land for a long time, were dead or yet to be born.

In the 1950s, Edith Clarke (1999 [1957]) had already drawn attention to the fact that this type of ownership, inheritance and use of Family Land was not static. There were, according to her, continuous internal and external pressures acting either to strengthen it or to modify it. At once, it created cohesion - keeping kinspeople together and preserving their mutual sense of responsibility and interdependence - and it also produced conflicts - linked, in specific, to controversies over individual or collective ownership of land, its alienability and inalienability. In Clarke's (1999 [1957]) view, they were shown to become exacerbated by national legislation, according to which an heir was only the first-born, legitimate male son, with full rights over the land, entitled to sell it, if he so wished.

In Old Bank, these pressures are evident in the local opposition between two temporalities: "first time" and "today". The first temporality is characterized by the existence of an apparent harmony to social relations, founded on the distribution of land according to the logic of "family land". The latter, in turn, is marked by conflicts, fights, problems and witchcraft. This opposition between "first time" and "today" emerged not only in genealogies, but also in informal conversations, and expresses the same kind of exacerbation caused by national legislation predicted by Clarke (1999 [1957]), and, in the case of Old Bank, also by tourism, among other critical factors detailed below.

\section{We don't live like [one] family}

One of the people who always shouted out my name when passing in front of my apartment was Mr Gabriel, who was 80 years old and enjoyed telling me stories about his life, as well as the histories of the village and its families.

Many people think that Afro-Caribbeans arrived in Panama during the construction of the $\mathrm{Canal}$, and later because of the Banana Industry. This is the history we learn in school. But there were Black Caribbeans here in the Bocas del Toro region long before this. They worked on the construction of railways here in Panama and Costa Rica, around the 1850 , more or less. It was only around 1930, 1950, that the Ngobe Indigenous people (Indígenas) began to arrive. They are not native to Bocas del Toro, they came from the [Panamanian] continent, first to work in the Banana Industry, and later to work in small businesses for tourists. Now they are the majority of inhabitants of Bastimentos Island. It is only here in Old Bank that we Blacks are still a majority.

According to Gabriel, there have been tourists in Old Bank since he was a child, but they were few, and people did not work in tourism like they did "today". When he was young, he also worked as a boatman, not taking tourists on trips - like boatmen would do during my fieldwork -, but, rather, transporting bananas and workers of the Chiriqui Land Company. This company was a subsidiary of the United Fruit Company, which continued to operate in the Bocas del Toro region "today" under the name of Chiquita Brands International.

His words echoed those of Gaia and other villagers, not only by making use of the same opposition between "first time" and "today", but also because it enacted the same economic markers - although Gabriel added another element, the construction of railways in Panama and Costa Rica. The information I was thus provided 
with was similar to that contained in the available literature on Bocas del Toro, according to which the current population of the region was mostly composed of people of Afro-Caribbean ancestry - that is, they were native to Panama and descended from free, Protestant Black people who came from the English Caribbean.

Referred to in the English-language literature as West Indians, these Black Caribbeans were hired during the $19^{\text {th }}$ and $20^{\text {th }}$ centuries to work in a number of British, French and North American endeavors in Central America (Newton 1984; Gutiérrez 1984), including: the construction of inter-oceanic railways in Costa Rica and Panama between 1850 and 1855 (Marín-Araya 2006); the construction of the Panama Canal between 1880 and 1914 (Maloney 1989; Lowe de Goodin 1999); and, finally, the operations of the United Fruit Company in Nicaragua, Costa Rica, Panama and Colombia, beginning in the 1880s (Bourgois 1985; Stephens et al. 1987). Having been employed in these different activities, often working in more than one of them during their lives, many of these Black Caribbeans did not return to their native lands. On the contrary, they and their descendants established themselves in the Panamanian region of Bocas del Toro (C. Reid et al. 1980; Spalding 2011; Howard 2014), and in other places, mostly in the Panamanian regions of Panamá and Colón (Westerman 1980), in the neighboring Costa Rican region of Limón (Duncan 1972; Bryce-Laporte 1973; Lefever 1992; Putnam 2002), and in other American and Caribbean territories (Coelho 2002 [1948]; E. Gordon 1998; Putnam 2013).

According to my interlocutors, the construction of the highway linking Panama City to the port of Almirante, and from there to Costa Rica, during the 1950s, moved the transportation of bananas, as well as other goods and people, to an overland route (that is, through Central America) rather than by sea, radically changing countless aspects of local dynamics. Up until that point, most of the commerce in the Bocas del Toro region was carried out in the surrounding Caribbean ports, which are precisely the places where most of the ancestors of the local families had come from. Furthermore, the Chiriqui Land Company started to hire workers who lived in the proximity of the highway, and terminated the daily ferry that connected the port of Almirante to Old Bank.

Almost all men of the village lost their jobs, and the economic crisis became a political crisis. Bastimentos, which has been an independent region, with its own seat of government, became subordinated to the governor of Bocas del Toro and the administrative agencies situated in Bocas Town (in Colón Island) and Changuinola (in the mainland). Later, with the development of tourism in Bocas Town in the 2ooos and the construction of an airport which became a hub for visitors, all boats transporting passengers to the region started to pass by Colón Island. Bocas town hence became the capital of the region, an obligatory stopover for anyone from Old Bank who wanted to go to the Panamanian continent, or anywhere else really, unless one had a private boat.

Tourism was always stressed as being among the most important markers in local historical narratives, and it was frequently related to the matter of land. One of the people I most often talked about this issue was a friend that, despite having no official role, was one of the main informal leaders in Old Bank, owner of the largest hotel in the village. For ten years, along with a group of coresidents, he had fought in court against the construction of a luxury resort on the island, some $2 \mathrm{~km}$ from the village.

According to him, the creation of the resort was linked to the development of tourism in the region following the earthquake of 1991. Since the tragedy was televised and transmitted to different countries, the beauty of Bocas del Toro gained world renown, boosting the local tourism industry. Since then, and particularly after the 200os, the local population began to sell their lands to developers for a pittance. In different ways, some villagers - such as the friend of mine I quoted above - began to go into business once they realized that the land had acquired financial value as a result of the influx of tourists. They sold only a part of their lands, mostly those that were farthest from the village and were used as "forest gardens". The money they made from this sale was used to transform their homes, and other buildings they may own, into simple hotels and some began to construct buildings to this end. Following the lead of these pioneers, other people followed the same route, like Gaia's sons and many other villagers. 
In agreement with the genealogical characterizations of the women I interviewed, this informal leader of Old Bank made explicit the fact that much of the land that was sold - or on which buildings for tourism were built - were not individual properties, but "family land" owned collectively. He said that, at inheritance, the land was traditionally divided between the sons and daughters, and a part of it - usually the part with the "family house" (fámili huôs), that is, the house where these sons and daughters had spent their youth - remained in collective ownership, so that it might be used by those who needed it. Even the land that was divided between the sons and daughters, or used only by some of them, nonetheless remained collectively owned. No one had a right to sell their land without the consent of their brothers. For this reason, sales became subject to disputes, since the tourist developments that multiplied the commercial value of the lands continued to grow.

The recurrent theme of the "family lands" was also stressed by my friend Hanna.

"First time", everyone in the village lived together, and they were generous, always sharing their surplus. We all "lived like family"! But not "today". Things changed when my brother sold the land that had belonged to my father. At the time, the government didn't sell land like they do "today". It only gave rights in usufruct, not the title to the land. The right of usufruct was my father's, and after he died it passed on to me. It was a "family land", my brother couldn't have sold it.

And, she continued,

My brother was the son of my mother only. She had him with another man, after my father died, and they lived in Almirante. When my brother moved to Old Bank and asked me if he could build his house there, I let him live on the land, but he sold it without telling me anything, or speaking to my brothers. These new neighbors were strangers to us, and they brought an end to the unity of the past. "Today", we no longer "live all like family".

While establishing the classic contrast between "first time" and "today", taking the sale of "family land" as a watershed, Hanna specifically referred to a change in national legislation concerning land ownership. This was not the first time I had heard comments regarding national legislation. Speaking to a man who was around sixty years of age, whose son lived in Panama City, and who therefore rented out his home in old Bank to foreigners, I was told that legislation changed around 2005, when it became necessary to buy and document the land. Previously, one only had to ask the owner for permission to build a house, or, if the land was unoccupied, to ask the local government. No payments were required, and no titles were given. However, when I asked civil servants in Bocas Town, the capital of the Bocas del Toro region, they informed me that legislation regarding the purchase of land had not itself changed. What had changed was people's relation to it.

According to these civil servants, the national legislation always required some form of payment to title plots and buy them (Panama 2009 and 1962). Formerly, however, people did not need to produce official documents that backed their claims, because they were not contested on these bases. Any contestation followed the logic of fámili lánd. People established themselves on their land after asking the government, or whoever lived previously on it, for permission, or else they inherited it. In the latter case, they would often have the appropriate documents proving their ownership, but these would be in the name of the first kinsperson who registered it, losing its validity by not being subsequently updated.

According to civil servants, it was only with tourist developments, though, that the existing national legislation became preeminent in the lives of the local population. Land prices went up in the market, which led people to dispute ownership, not only among each other, but also with foreigners who wanted to buy pieces of land and non-resident kinspeople interested in selling, rather than settling on them. It thus became necessary to title land and to buy it, in order to preclude others from doing so, thereby acquiring legal rights over the disputed land. Indeed, as pointed out both by my interlocutors and the literature on Bocas del Toro (Thampy 2013), instances of land disappropriation became common, particularly concerning the plots where 
Indigenous Ngoebe people live, even if they had lived on the plots for years 5 . Likewise, there were instances of non-residents returning to claim their rights over "family land" that they had recently titled, but that had long been gifted to others in usufruct by a deceased relative.

In Hanna's speech, as in that of other interlocutors, "today" is a temporality marked by the concomitant processes of the sale of "family lands", the decline of the Banana Industry in the region 6 , and the development of tourism. According to her, by the conjunction of these temporal markers, most men went to work as boatmen for tourists, and only a few continued to work in the port of Almirante for Chiquita Brands International. At the same time, another parcel of residents, including men and women, were employed in restaurants and hotels for tourists, as kitchen or cleaning staff, or in other client services for tourists. Others still went into personal business ventures for tourists, offering boat rides, cooking at home to sell to locals and foreigners, renting rooms for tourists, and so forth. Finally, there were those who received government benefits. Almost no one, however, earned more than minimum wage (approximately US 400.00 per month), paid out in bi-weekly tranches. Regardless of the source of income, the money received by the local population tended to be used up in a few days, in part because Old Bank is an expensive village by Panamanian standards, mostly due to tourism - I would myself spend an average of US $\$ 500$, oo per month on rent and food, and I lived alone, while most locals were the sole providers for households of five people on average. For the rest of the time, the villagers managed without money, consuming what they planted or what was left over. They also received food from friends, kinspeople and neighbors, since they were used to sharing food, particularly when they cooked in abundance, or for a special occasion.

It should be recalled, however, that Hanna stressed that the habit of sharing food with friends, neighbors and kinspeople was typical of the "first time" temporality. It was associated with the very dynamics of "family land": people were neighbors because they were related and/or friends, that is, because they had received from or conceded to others permission to live on the land, to build a house on it and/or to plant a garden. This was the case not only for each plot of "family land" but also for Old Bank as a whole. As my friend stated, "everyone in the village lived united and was generous, always sharing surplus. We all "lived like family"!". Hanna thus implicitly defined what "living like family" meant, understanding it as pattern of relationships based on reciprocal care, on generosity and on sharing: "Today we no longer live like family", she lamented.

On a first hearing, these words made me think that changes had occurred either by the loss of land to speculation, or by the appearance of foreign people, or, still, by a view of migration and mobility as processes that are disruptive of social relations. However, this initial impression did not correspond to what my interlocutors experienced. On many occasions they pointed out that there always had been tourists in Old Bank - even though only a few ventured that far in the old days - and that contact with people from other places was a constant aspect of the history of the village and its local families. Their own founding ancestors had been foreigners, and many of them had married people of Ngoebe, Chinese, Latin, Panamanian and White descent. Furthermore, the vast majority of villagers had lived elsewhere for a while, or had travelled to different villages and cities to study, work, go to the doctor's or visit kinspeople. Everyone I spoke to during my fieldwork had at least one relative (son, brothers and sisters, parents, grandparents, uncles, or cousins of either sex) who resided somewhere else and returned periodically to visit and to rekindle ties with those who had remained in the village.

\footnotetext{
5 The matter is complex and warrants a further comment. These plots in which the Indigenous Ngoebe people lived in the region of Bocas del Toro were the same plots claimed as "family land" by Afro-Caribbeans. They were therefore not ancestral Indigenous Lands, since, as I mentioned earlier, the Ngoebe were not native to the Bocas del Toro region. They migrated during the $19^{\text {th }}$ and $20^{\text {th }}$ centuries, coming from other lands in continental Panama, which had been recognized by the Panamanian government and demarcated as Ngoebe Indigenous Lands.

6 This decline was partly due to the construction of the highway, which reduced the Banana Industry's activity in all port (as mentioned above), and was also due to the fact that the company underwent mechanization and needed less employees.
} 
Taking this set of elements into account, even if the sale of "family lands" was linked to the end of an economic cycle (bound up with the Banana Industry) and the start of another (based on tourism), what seemed to be in play was a demographic, economic, and even moral crisis. Indeed, insofar as "first time" was described as a period of wealth, when compared to the losses of "today", it was equally a time of scarcity - for example, of street pavements, electricity, and foodstuff which is consumed in abundance in the temporality of "today", such as chicken. Furthermore, when speaking of this temporal process, people not only lamented the loss of their land for its economic value - and hence its financial value, but also its potential for agriculture and animal husbandry in a capitalist perspective or in a subsistence and barter economy - they also described this loss as a "theft" (adding a moral value), either because of tourist entrepreneurs which bought the land at very low prices, or because of people who used subterfuges to appropriate the land, such as producing fake documents, or selling land that they were only entitled to live on. The people I spoke to seemed to condemn the sale of land in itself, since this kind of action established relations of vicinage through commercial transactions, rather than through personal ties based on "family land". They thus emphasized historical changes that entailed changing economic, kinship and neighborhood relationships. Yet such relationships were not limited to those established between human beings only.

\section{We [don`t] live with God}

You want to know the history of this place? My grandmother used to tell me stories of Miss Abi. [...] Before she arrived, there were Black witches (blák obeamán) living in the extremes of Bastimentos Island. They were the first inhabitants of this place, and they came directly from Africa, having never been enslaved. They knew how to make witchcraft (obeá) and control the spirits of the dead. They fought amongst themselves and sent spirits to kill each other's relatives. The victims were buried where the village now stands. First time this was a graveyard, but Miss Abi brought the word of God, which put an end to witchcraft and to the rivalry between these first families. They were baptized in the Methodist Church that was built where this graveyard would be and all of them started to live with God.

Yet again, I received an unexpected answer to my insistent questions about the history of the village and its local families. This time it came from a local young man, some eighteen years of age, who did not usually go to Church, but learned from his grandmother stories of Miss Abi, a Black Methodist missionary who arrived in Old Bank in 1814. Others had already told me that the Methodist Church would celebrate its $200^{\text {th }}$ anniversary in 2014, and that it was the oldest religious institution in the village, followed by the Adventist Church (the only other on that had an actual church building in the village). However, I had never heard that story of Black African witches, nor of a Black missionary who brought the word of God.

In this story, God and Black people who had lived and died in the island (witches and Christians) were all referred to as autonomous agents, who were accountable for actions and relations that had concrete effects on living human beings and the spaces they inhabited. Witches knew how to control the spirits of the dead (which, although active, do not appear to have had autonomous agency) and they sent these spirits to kill each other's relatives. In 1814, however, Miss Abi changed all this: she brought the word of God and built the Methodist Church where the graveyard used to be, and where the village would later be erected. The word of God thus put an end to witchcraft and rivalry between the first families, which were baptized and started to "live with God" (liv uid Gád). These changes were materialized in space: the Methodist Church built on one of the highest points, and, on another high point, in the extreme east of the village, was the current graveyard, almost in the forest. 
My curiosity was piqued by this, and I began to ask other people about this missionary. A woman whose surname was Davies and who had been baptized into the Methodist Church, attending services since she was a child, told me she also heard stories of Miss Abi, or Mother Abel (Mis Aby, Mis Abee), as she was called in the historical text kept by the pastor (Araúz Monfarte 2007). Although she did not know many details about this missionary, or about the people of the village in 1814 , she knew the consequences that the missionary's visit left throughout the $2 \mathrm{o}^{\text {th }}$ Century. This is what Mrs Davies told me:

My grandmother told me that when she was young the people of old Bank would spend the weekend in Church: they went to the Seventh-Day Adventist Church on Saturday, and to the Methodist Church on Sundays. The Adventist Church has also been here for a long time, at least since 1902. Our Methodist and Adventist church buildings were the first in Panama! In the days of my grandmother things were not like "today", when those who go to one church don't go to the other, and most people only think of God when they have a problem. In the old days it was not like this, and everyone in Old Bank lived with God!

As both oral narratives and the historical record of the Methodist Church make clear, both the Methodist and the Adventist messages were taken to Old Bank by missionaries coming from the Caribbean. Both established church buildings in Old Bank before expanding to the surrounding islands and the Panamanian continent, as well as Costa Rica. Although the literature has tended to overlook this fact, it attests to the importance of Old Bank in the Bocas del Toro region, the village seemingly providing a bridge between the Caribbean and Central America in the $19^{\text {th }}$ and $20^{\text {th }}$ centuries.

Although the Adventist Church arrived in Old Bank nearly a century after the Methodist Church, there was no specific story concerning its missionaries, much as there were no stories associated with missionaries from other Protestant Christian denominations that later visited the village (the Jehovah's Witnesses, for example, who went weekly to the village during my fieldwork). All that was said of the Adventist missionaries is that they were two men, John Eccles and John Hocking, both described as being White, and having died in the village in 1902, as registered in their tombstones, conserved in the gardens of the current Adventist church building. It was thus known that the institution had been present in the village since 1902, even if the church building had closed around 1950 and then re-opened, in the same place where it had been founded, only in 2008. The reason why it had been closed for some fifty years was unanimous: conflicts involving land inheritance, or course.

Some of the aspects of the story of Miss Abi, in contrast, drew my attention more. First, the stories of Miss Abi offered clues of the existence of a Black community in Bocas del Toro in the $17^{\text {th }}$ Century. There are few historical records of Bocas del Toro before the $19^{\text {th }}$ Century, when North American economic developments began to affect the region. According to these records, throughout Central America the Spanish Empire was concentrated in the Pacific coast, and, up until the $19^{\text {th }}$ Century, did not effectively colonize the Atlantic coast, which was disputed by a number of actors. Among these were small native Indigenous groups - in the Bocas del Toro and southern Costa Riva these were the Teribe - who, after the Spanish invasion led by Christopher Columbus in 1500 , migrated to the interior of the continent to escape death and enslavement in the periodic ambushes they suffered from European seamen (particularly British, Dutch and French pirates) and sailors of the Miskito commercial empire (Stephens et al. 1987). The Miskito are made up of more than thirty native groups from the Atlantic coast and the current territories of Honduras and Nicaragua, and their history is similar to that of the Garifuna. They are of Amerindian and Black descent, having incorporated, during the $17^{\text {th }}$ Century, the descendants of Africans who either survived shipwrecks (possibly after rebelling while they were being transported in slave ships) or fled slavery in the continent (Cwik 2014).

Historiography tells us that Bocas del Toro had remained uninhabited after the Teribe left in the $16^{\text {th }}$ Century, right up until the first decades of the $19^{\text {th }}$ Century. During this time, Methodist missionaries and British colonists arrived in the archipelago (C. Reid 1980). They brought to the archipelago their families, their plantations, and 
the enslaved population that worked on them, because of the high taxes charged by the British Crown, which at the time controlled the islands of San Andres and Providencia, where they were established (Stephens et al. 1987). Shortly after arrival, these colonists emancipated the enslaved population - probably because they did not have a European contingent large enough to deter escapes or control revolts. This population formed autonomous communities, like Old Bank, based on an agricultural and fishing subsistence economy, and on waged work after the establishment of the Banana Industry in the region. This attracted others to the village (Afro-Caribbeans, mostly from the Jamaica), along with Panamanian-Latinos, Ngobe Indigenous people, Chinese and other foreigners (Guerrón-Montero 2006).

Yet the information I obtained in the field concerning Miss Abi provide information which complements history, and suggests the following possibility for future study. Before the $19^{\text {th }}$ Century, Old Bank was already a settlement made up mostly of Blacks who had survived shipwrecks or fled enslavement - much like the people of African descent incorporated by the Garifuna and the Miskito. We might also suppose that the history of these three groups of Blacks from the Central American Caribbean were not unfolding in parallel to each other, but rather cut across one another, due to the similarities of their languages (Central American English Creoles), their funerary rites (nightly vigil culminating on the ninth night), their relationships with the slave economy (they do not recognize descent from enslaved people) and with North American imperialism (they flowed between the same economic initiatives established in Central America between the $19^{\text {th }}$ and $20^{\text {th }}$ centuries). Since these histories and hypotheses are beyond the scope of this article, I invite other authors to explore other ways in which ethnography can contribute to the historiography and archaeology of Old Bank, and other places.

Many of the people who spoke to me of the Methodist missionary took this fact as a temporal marker through which a further contrast between "first time" and "today" was established. This contrast foregrounded a sort of origin myth of the village of Old Bank, delimiting three moments in time. Two of them were marked by temporalities prior to the sale of "family land" - that is, they were earlier than the temporalities of "first time" and "today". The third, finally, was contemporary to the sale of the land.

The first of these moments was before the arrival of Miss Abi, and was characterized by witchcraft, fights and deaths: during this time, the whole area of the village was a graveyard. Returning to the discussion of the previous section, the way people lived during this time (and the way they live in the present) was the opposite of the relational pattern summed up in "living like family". There is a rupture between the first and the second period caused by the arrival of Miss Abi, who brought with her the word of God: thenceforth people began to "live with God".

The narratives did not transmit detailed information about the missionary. No one in Old Bank recognized her as an ancestor, nor was she mentioned as a friend of the ancestors of any of the families in Old Bank perhaps because her stay there had preceded her arrival by some one hundred years. In turn, the people that she encountered in Old Bank, described as Black witches, were not recognized as ancestors to contemporary families. In this way, these narratives have no direct connections to people who exist in the present.

In the narratives concerning the period after the passage of Miss Abi, the relations of living people with the narrated facts was changed by the passing of the years. The village of Old Bank already existed and corresponded to the place described by the grandfathers, starting with the first ancestor to leave the Caribbean and arrive at the village. To a degree, this time coincided with the heyday of the Banana Industry (between 1870 and 1960), during which the village reached its economic and moral boom, characterized by an assiduous Christianity, in which everyone "lived with God", by harmonious and generous practices of conviviality exercised on "family land", when everyone "lived like family". 
This second period, following local narratives, was interrupted by a moral decadence, which thus began the third time, "today", when people no longer live in harmony, God is no longer important, people only think of him when they have a problem, and people do not attend mass like they used to. As such, this third temporality is an inversion of the second. In the second period, emphasis is placed on the positive ruptures caused by an approximation to God, while in the third emphasis is placed on negative changes resulting from a distancing from God. Echoing the temporality of "today" described in the above section, this third time is characterized by a moral crisis linked to the sale of "family land" and the fact that people no longer "live like family". At the same time, it was associated with a distance from God and the fact that people no longer "lived with God". What appeared to be emphasized were historical changes linked to tourism and national legislation, and also those that implied changing relations between people and God, which, in turn, resulted in historical transformations. It was not simply a matter of changes in relations between human beings themselves, but also in relations between human and non-human beings - such as deities and spirits of the dead.

Thus, the two contrasts established in the histories of Old Bank between "first time" and "today" had different, but not unrelated, phenomena as their watershed: on the one hand, the sale of "family land" (connected to tourism and national legislation); on the other, a distancing from God. Analyzing these two contrasts, I noticed that both of them pointed to two moral crises (themselves present in both the past and the present) which, in their difference, were conjugated and formulated, respectively, in terms of not "living like family" and not "living with God". In other words, these two contrasts suggested that relations between human beings themselves were distinct, but not unrelated, to those established between human beings, witches, spirits of the dead and God.

\section{Building relations locally}

Tim Ingold (1993) argues that human life corresponds to the temporal process of the constitution of the place in which human beings live. Seeking to overcome the dichotomy between the natural (scientific or objective) and human (cultural or artificial), as well as that between technology and society, he introduces the concept of the "landscape", defined, precisely, as long-lasting register of and witness to life and the work of past generations. In every generation, as well as across generations, human beings leave something of themselves in the "landscape", thereby producing and reproducing it. The "landscape" is hence necessarily impregnated with the past and history, that is, with the pattern of activities inherent to a "taskscape".

The author defines "landscape" as an incorporated form of activities or tasks. As such, "landscape" corresponds to the constant process of generating the forms that compose it. This process is realized by means of the mutual interaction of forms - and not through a process of the inscription of culture on a natural substrate that is previously given. Temporalities, spacialities, materialities, and socialities are produced through dwelling, that is, in the dynamic process of interaction which is always suspended in movement and makes itself present only as task and activity. Ingold thereby draws attention to the fact that a "landscape" can be heard, and not just seen. "Landscape" does not materialize all at once, in the blink of an eye, as when we observe a painting. It is produced processually, and although the eyes may not register the differences between each instance of this process, the ears clearly apprehend the distinctions produced by them - that is, by the tasks and activities that are occurring and by the forms in movement.

It was by hearing, and not just seeing, that I apprehended the spatial and temporal dimensions during 14 months of fieldwork in Old Bank. Stories about families, land, witches, missionaries and God allowed me to understand that relations were maintained between and by human beings themselves - including relations between dead human beings or those described as witches - and the relations among humans, spirits of the dead and God, which composed the times and spaces of the village. Facts which were incorporated into memory, 
and those which were not, expressed a local emphasis on personal experience in what concerns obtaining and transmitting knowledge. They thus enabled the paths of experience of my interlocutors to be mapped, revealing which relations were maintained, when, where and with whom. Moreover, they illuminated ways in which ethnography can contribute to historiography and archaeology, retelling the history of Black Central America and conveying the centrality of places such as Old Bank.

It is possible to discern, from the words quoted above, contrasts between "first time" and "today", which conveyed information on the dynamics of land occupation, use and distribution. These dynamics resonated with a classic theme in the ethnographic literature on other Afro-Caribbean contexts, with the logic of "family land" in Old Bank being analogous to its Caribbean homonym, particularly in what concerns Jamaica, where many of the ancestors of the current inhabitants came from. As Edith Clarke (1999 [1957]) showed, the inheritance of Family Land implied a concept of the family that included all descending relatives (paternal and maternal sons and daughters), but not affinal relatives (male or female spouses), much less sons and daughters that were born only to the (male or female) spouse in another relationship. Jean Besson (2002) took this argument further, describing the family as an open group based on inclusive criteria, since it is defined, precisely, by the ownership of Family Land, focused on the control over the progressive growth of the group through relations of paternal and maternal filiation.

In Old Bank, the family was defined by the ideas and practices inherent to "family land", which were locally formulated in terms of "living like family". Significantly, it was because they descended from the same founding ancestors, and inherited their "family land" from them, that my interlocutors claimed that "we are all family". Furthermore, the moral crisis that characterized the temporality of "today" was associated with the sale of "family land", since it was during this temporality which national legislation, tourism and other developments affected relationships, people "did not live like family" and "did not live with God". According to my interlocutors, this resulted less in an impoverishment, than in a moral transformation: a change in the relations of human beings themselves and of human beings with non-human beings, such as God.

In the conversations I had during fieldwork, God emerged gradually, such as in the expression "God first", uttered by Gaia's son in the day we met, and by other villagers on other occasions. In the story of Miss Abi, however, God emerged more prominently, alongside references to witches, spirits of the dead and witchcraft, which had themselves appeared, unexpectedly, in narratives about "family land" and the conflicts surrounding it. These references to witchcraft revealed a synonymy between acts of not "living like a family" and not "living with God", since both implied maintaining family relations (such as those widely diffused in the village "today") marked by rivalry, fights and problems. Conversely, "living like family" and "living with God" seemed to be equivalent according to the values of "family land", involving generosity, harmony and the exchange of surplus (of land or food) between people.

Old Bank thus adds a new element to Clarke's (1999 [1957]) and Besson's (2002) arguments, since, in this case, the family group is not solely defined by relations among human beings themselves (living and dead), but also among them, spirits of the dead and God. Indeed, the Old Bank "landscape" incorporated the tasks and activities of them all: on the one hand, the activity of witches controlling the spirits of the dead, and the activity of God, who brought an end to witchcraft and rivalry between the first families; on the other, the daily tasks of human beings, whether they do or do not "live like family" and "live with God".

Thus, in the temporality of "today", the moral crisis was associated with a distancing from God and the sale of "family land", as well as with tourism and national legislation. Even if the causes of this distancing were not developed, the counterpoint between "first time" and "today" featured the development of tourism as an aggravating factor in the moral crisis, since it added speculative pressure on lands. As Gaia stressed, in the temporality of "today" there is not as much land as in the 'first time'. Back then, no one thought of building in the spaces underneath houses. With tourism, however, these spaces were transformed into apartments. 
The new spacialities of the apartments differed from the dwellings of "first time", despite the fact that the former were literally attached to the latter. These two spacialities, of the house and the apartment, were therefore different but not separate. In this sense, the contrast between "first time" and "today" - which was expressed orally, and could thus be heard more than seen - found a direct, and visible, material expression in the contrast between the spacialities of the houses and the apartments. In the midst of this, bridging such contrasts, separations and differences, were the shouts. And, along with them, other oral forms of transmitting knowledge and linking, not only people, but also temporalities and spaces.

Received: September 24, 2019

Approved: February 10, 2020

Translated by: Luiz Costa

\section{Bibliography}

ACETO, Michael. 1995. "Variation in a secret creole language of Panama." Language in Society, 24(4): 537-560. ARAÚZ MONFARTE, Cèlestino Andrés. 2007. Bocas del Toro y el Caribe Occidental. Periferia y Marginalidad, siglos xvi-xix. Bocas del Toro: Instituto Nacional de Cultura.

BESSON, Jean. 1984. "Family land and Caribbean society: Toward an ethnography of Afro-Caribbean peasantries." In: Elizabeth M. Thomas-Hope (org.), Perspectives on Caribbean Regional Identity. Liverpool: Center for Latin American Studies/ University of Liverpool. pp. 57-83.

. 2002. Martha Brae's Two Histories: European Expansion and Caribbean Culture-Building in Jamaica. Chapel Hill: University of North Carolina Press.

BOURGOIS, Philippe. 1985. Ethnic Diversity on a Corporate Plantation: Guaymi Labor on a United Fruit Company Plantation in Panama and Costa Rica. Cambridge: Occasional Paper No. 19 of Cultural Survival.

BRERETON, Leticia C. Thomas. 1992. An exploration of Panamanian Creole English: Some syntactic, lexical and sociolinguistic features. PhD Dissertation, University of New York - New York.

BRYCE-LAPORTE, Roy Simon. 1973. "Family, Household and Intergenerational Relations in a 'Jamaican' Village in Limón, Costa Rica." In: N. Gerber (org.), The Family in the Caribbean: Proceedings of the Second Conference on the Family in the Caribbean. San Juan: University of Puerto Rico Institute of Caribbean Studies. pp. 65-93.

CARNEGIE, Charles V. 1987. “Is family land an institution?” In: (org.), Afro-Caribbean Villages in Historical Perspective. Kingston: African Caribbean Institute of Jamaica. pp. 83-99.

CLAIRBORNE, Petra. 2010. Community Participation in Tourism Development and the Value of Social Capital-the case of Bastimentos, Bocas del Toro, Panamá. Disponível em: <https:/|gupea.ub.gu.se/bitstream/2077/22603/1/ gupea_2077_22603_1.pdf_. Acesso em: 26 dez. 2016.

CLARKE, Edith. 1999 [1957]. My Mother Who Fathered Me: A study of the families in three selected communities of Jamaica. Mona: University of West Indies Press.

COELHO, Rui. 2002 [1948]. Os Caraibas Negros de Honduras. São Paulo: Perspectiva. 
CRICHLOW, Michaeline A. 1994. "An alternative approach to family land tenure in the Anglophone Caribbean: The case of St. Lucia". New West Indian Guide, 68(1/2): 77-99.

CWIK, Christian. 2014. "The Africanization of Amerindians in the Greater Caribbean: The Wayuu and Miskito, Fifteenth to Eighteenth Centuries". In: Franklin Knight; Ruth Iyob (orgs.), Dimensions of Diaspora. Kingston: University of the West Indies Press. pp. 298-329.

DUNCAN, Quince.1972. El negro antillano: inmigracion y presencia. San José: Editorial Costa Rica.

GORDON, Edmund Tayloe. 1998. Disparate diasporas: identity and politics in an African Nicaraguan community. Austin: University of Texas Press.GUERRÓN-MONTERO, Carla. 2006. "Tourism and AfroAntillean Identity in Panama." Journal of Tourism and Cultural Change, 4(2): 65-84.

GUTIÉRREZ, Samuel A. 1984. Arquitectura de la época del Canal, 1880-1914, y sus paralelos norteamericanos, franceses y caribeños. Ciudad de Panamá: EUPAN.

HOWARD, Jerry J. Jr. 2014. Emergent Identities in the African Diaspora. The Bocas Way. PhD Dissertation, University of California - Berkeley.

INEC, 2009-2010. Instituto Nacional de Estadistica y Censo. 2009-2010. Census and Cartography.

Ciudad de Panamá.

INGOLD, Tim. 1993. “The temporality of the landscape.” World archaeology, 25(2): 152-174.

JUSTAVINO, Nilsa. 1975. West Indian English dialects in Panama: A historical, social and linguistic approach to West English dialects in Panama. Ciudad de Panamá: Universidad de Panamá.

LEFEVER, Harry G. 1992. Turtle bogue: Afro-Caribbean life and culture in a Costa Rican village. London \& Toronto: Susquehanna University Press.

LOWE DE GOODIN, Nelva. 1999. De/from Barbados a/to Panamá. Ciudad de Panamá: Editora Géminis.

MALONEY, Gerardo. 1989. El Canal de Panamá y los trabajadores antillanos: Panamá 1920: cronología de una lucha. Ciudad de Panamá: Ediciones Formato 16/ Extensión Universitaria/ Universidad de Panamá.

MARÍN-ARAYA, Giselle. 2006. "Proyectos para construir una ruta transítmica en la zona limítrofe de Costa Rica y Panamá en el siglo XIX.” Revista de Historia de América, 137: 131-165.

MINTZ, Sidney W. 1974. \&quot;Houses and Yards among Caribbean Peasantries\&quot;. In: (org.),

Caribbean Transformations. New York: Columbia University Press. pp. 225-250.

NEWTON, Velma. 1984. The silver men: West Indian labour migration to Panama, 1850-1914. Mona: Institute of Social and Economic Research/University of the West Indies.

OLWIG, Karen Fog. 1999. "Caribbean place identity: From family land to region and beyond.” Identities Global Studies in Culture and Power, 5(4): 435-467.

PUTNAM, Lara. 2002. Company They Kept: Migrants and the Politics of Gender in Caribbean Costa Rica, 1870-1960. Chapel Hill: University of North Carolina Press. . 2013. Radical Moves: Caribbean Migrants and the Politics of Race in the Jazz Age. Chapel Hill: University of North Carolina Press.

REID, Carlos et al. 1980. Memorias de un criollo bocatoreño. Ciudad de Panamá: Asociación Panameña de Antropología.

REID, Heidi. 2013. "Bastimentos Creole English, Bocas del Toro, Panama”. Disponível em: <https://heidireidmanchester.wordpress.com/extra/>. Accesso em: 04 mar. 2017.

SNOW, Peter. 2007. "Vernacular shift: Language and the built environment in Bastimentos,

Panama." Identities: Global Studies in Culture and Power, 14(1-2): 161-182.

SPALDING, Ana K. 2011. Re-making lives abroad: Lifestyle migration and socio-environmental change in Bocas del Toro, Panama. PhD Dissertation, University of California - Berkeley.

SPRAGG, Marva Myles. 1973. Origin and nature of the English dialect of Colon and its implications for the teaching of standard English. Ciudad de Panamá: Universidad de Panamá. 
STEPHENS, Clyde Schubert; MOTTA, Marianela de; MORENO, Stanley Heckadon. 1987. Bosquejo histórico del cultivo del banano en la provincia de Bocas del Toro (1880-1980). Ciudad de Panamá: Publicado autonomamente pelos autores.

THAMPY, Gayatri. 2013. Indigenous contestations of shifting property regimes: Land conflicts and the Ngobe in Bocas del Toro, Panama. PhD Dissertation, Columbus: The Ohio State University.

TROUILLOT, Michel-Rolph.1992. "The Caribbean Region: an open frontier in anthropological theory." Annual Review of Anthropology, 21:19-42.

WESTERMAN, George W. 1980. Los immigrantes Antillanos en Panama. Ciudad de Panamá: Impresora de la Nacion.

\section{Claudia Fioretti Bongianino}

Doctor in Anthropology and Researcher at the Anthropology and History Laboratory of the National Museum of the Federal University of Rio de Janeiro (LAH/MN/UFRJ)

https://orcid.org/oooo-0003-1531-2093

Email: Fioretti.claudia@gmail.com 